\title{
Persistence of Features of Traditional Healing in the Churches in Africa: The Case of the Akurinu Churches in Kenya
}

\author{
Nahashon W. Ndung'u \\ Department of Philosophy and Religious Studies \\ University of Nairobi, Kenya \\ nndunguwamathai@yahoo.com
}

\author{
Thought and Practice: A Journal of the Philosophical Association of Kenya (PAK) \\ New Series, Vol.1 No.2, December 2009, pp.87-104 \\ thoughtandpractice@gmail.com OR thoughtandpractice@uonbi.ac.ke
}

\begin{abstract}
One of the attractions of new converts from mainline churches to the African Instituted Churches (AICs) is faith healing. Healing understood in its wider sense as the restoration of the wholeness of life is not new to African communities, since they practiced it long before the coming of Christianity into their continent. This article examines some features of traditional healing which are manifested in faith healing in the AICs. The persistence of these features pauses a challenge to mainline churches in Africa, forcing them to rethink their approach to life threatening issues such as witchcraft and barrenness that continue to preoccupy many of their adherents.
\end{abstract}

\section{Introduction}

Throughout human history, the search for good health or wholeness of being has been a major concern. The search for drugs to confront incurable diseases continues to occupy medical professionals worldwide. Physical suffering, however, is only one of the problems facing humanity. There are several other crises of a social, economic, psychological or spiritual nature that confront men and women. 
Within the African worldview, life is seen in its totality rather than in segments. People are at peace when their relationship with God, the spirits, other people and the rest of creation is good (Mbiti 1969, 2). A broken relationship spells disaster for the individual, and, by extension, for the rest of the family and society at large. Consequently, a remedy has to be sought to bring back the wholeness of life to the people. This process of making right the wrongs responsible for the sufferings can be seen as a healing process in which an attempt is made to mend broken relationships. In comparing Western and African understanding of health and healing, Edwina Ward $(2002,55)$ makes the following observation:

For African people life is a continuum of social, cosmic, personal and communal events. When one breaks the moral codes of society then the ties between oneself and community are also fragmented. Thus in the case of illness it is not the individual who is seen as needing healing but the broken relationships which needs to be healed. The Western mind remains individualistic and views the problem as physical or emotional and needing the healing of modern medicine.

In this paper, we shall use the term healing in a holistic sense to imply the putting in order of those systems, structures and feelings which have been disrupted causing imbalances and suffering in the life of individuals and society at large.

Globalization with its baggage of rapid social change has impacted rather negatively on the African communities. Individuals are exposed to new world views with strange values, while the youth are torn away from their cultural bonds. In short, people have become lonely - strangers to themselves and living in a morally bankrupt and spiritually confused society. Others have been economically marginalized, resulting in spiralling poverty.

In the midst of this state of confusion and desperation, New charismatic movements have emerged, with origins in the West and East which promise to offer a host of instant remedies to all kinds of problems facing the people - ranging from sickness, domestic quarrels, poverty and all forms of misfortunes(Vahakangas and Kyomo 2003; Gifford 1992). Some of these New charismatic movements refer to their churches as "miracle" or "healing" centers. The proliferation of these "healing" centers in the last two decades in the urban areas in Africa is a reflection of the state 
of a society undergoing a difficult period socially, economically, politically and psychologically. The hopelessness which results inevitably drives individuals to seek for solace and hope. Churches which practice faith healing therefore become attractive to people with diverse needs. Shorter and Njiru $(2001,30)$ rightly observe:

Charismatic movements have arisen out of a drastically changed social, economic, religious, moral and spiritual order, an order that has happened to make very many people uncertain in their lives at all levels.

Nevertheless, the phenomenon of holistic healing is not new in Africa (Magesa 2004, 68). Long before the coming of Western Christianity, Africans had their own medicine-people and diviners who provided healing services. Furthermore, the classical African Instituted churches (AICs), which arose soon after the missionfounded churches, were engaged in healing, making them attractive to many Africans. In South Africa for example, Sundkler gives an account of Isaiah Shembe, the founder and prophet healer of the Nazarite Church. Shembe had led his followers to take a sacred oath not to resort to medicine in any shape or form, nor to submit their bodies to the cut (Sundkler 1964, 227). For any problems befalling a member of this church, he/she had to seek a solution from the prophet. His village of Ekuphakameni essentially became a healing center. Their refusal to use western medicine brought them into a collision course with the government (Sundkler 1964, 227). Since 1926, the issue has been of grave concern to the administration in Natal. The Nazarites' refusal to allow vaccination of their church members has been a menace to the rest of the community.

Simon Kibangu, founder of Kibanguist Church, similarly emerged as a prophethealer around 1921 in the present-day Democratic Republic of Congo. After two initial healings, he attracted multitudes of people who thronged his village of N'kamba in search of healing. N'kamba, like Shembe's Ekuphakameni, became a healing centre with a sacred spring adjacent(Martin 1975, 45). Similarly, Oshitelu, the founder of the Aladura(praying) churches in West Africa, called people to "hear the Gospel of joy ... and ... divine healing, the curing of all woes and ailments, ... an offer of blessings in all one's troubles through faith in God alone ......" (Turner Vol.I, 1967, 27). The great attraction of people to the Aladura healing centers is illustrated 
by Turner( Vol.I 1967, 27), when he cites a report sent to the Anglican Bishop of Lagos in 1931:

Unfortunately, the belief spread that all sickness could be cured by drinking water which had been blessed by the Aladura, and the result was that the province was inundated with lepers .... and people suffering from all sorts of loathsome diseases .... who swarmed into the towns and built huts in close proximity to the Aladura's pulpits ......and were polluting the drinking water

The same could be said of the Lumpa church of Alice Lenshina of Zambia, which she founded in 1951. Her attraction revolved around her ability to diagnose and offer solutions to diverse social problems as the following account of those who came to her illustrates:

6 families said that their children were sick, 4 that a child had died recently, 4 that they had dreamed of being bewitched and 3 that they sought protective medicines against witches. The last was a headman who believed that his villagers were leaving him because they thought he was a witch. He went to Alice to prove that he was not (Bond 1979, 147).

As a case study on healing, the article examines the healing procedures carried out among the Akurinu churches. These are spirit churches that emerged among the Gikuyu people of Central Kenya in the late 1920's, and continue to thrive to the present day(Ndungu 1994). The study has three objectives. First, it aims to identify the traditional holistic healing approaches among the Gikuyu community. Second, it examines ways in which these traditional healing procedures have persisted among the Gikuyu Christians as demonstrated in the Akurinu churches. Third, it argues that holistic healing as practiced in the AIC's is indeed a deeper level of inculturation of the gospel.

\section{Healing In Traditional African Communities}

Every African community had in place mechanisms of dealing with anti-life forces like diseases, drought, floods, barrenness, curses and witchcraft. These maladies, according to the Africans, did not occur by accident, but were caused by certain forces, including human agents through magic and witchcraft. Furthermore, such misfortunes were seen as religious experiences requiring a religious approach to dealing with them (Magesa 1988, 159; Mbiti 1969, 169) It is for this reason the 
services of the medicineman, diviner or herbalist were sought. The medicineman in particular has been described by Mbiti $(1969,166)$ as the greatest gift and the most useful source of help. While dealing with a problem, he followed an elaborate procedure whereby he identified the nature of the problem, the cause and the cure or solution (Rukwaro 2005). This process is both psychological and physical. Mbiti $(1969,169)$ sees the psychological aspect as the equivalent of spiritual healing in our modern times. The process of healing depends by and large on the role of the patient. $\mathrm{He} / \mathrm{she}$ must play his /her role during the whole process (Leakey 1977, 1146). Among the Gikuyu for example, it is the patient or relatives who approach or invite the medicineman. This in itself is an acknowledgement that life is in danger and a remedy is urgently required.

According to Kenyatta, the patient was expected to participate in the healing process. $\mathrm{He} / \mathrm{she}$ had to lead the way by confessing to the medicine man his/her sins as the following conversation illustrates:

Sick man I have come to chase away your illness. I will also chase away the evil spirits which have brought it. Confess the evils you know and those you do not know. Prepare yourself, for you are about to vomit all these evils (Kenyatta 1938, 157).

During the cleansing ritual that followed, the patient was to symbolically vomit all the known and unknown evils into a hole with ceremonial water. This he did by licking the ceremonial gourd(Githitu), and then spitting into the hole as he proclaimed, "I vomit the illness and the evil spirits that are in my body" (Kenyatta 1938, 157). Through this ritual, the patient was given an assurance that all was well. Perhaps the assurance that the problem will not recur is what distinguishes the traditional and the modern medical practices. Whereas our modern doctors deal with the physical aspects of a disease, they do not answer such pertinent questions as "why" the attack and "how" to avoid a recurrence. Their advice is that "if you fall sick again, consult a doctor." In the traditional approach to healing however, the patient not only gets the treatment, but also an explanation as to why he/she fell sick, and an insurance cover in form of protective charms against people with evil eyes, or he/she performs an action which forestalls a recurrence of the problem. It is this assurance that is driving all and sundry to the medicinemen in the modern times. 
An important feature in the healing process is its communal aspect. In modern medical practice, the patient can keep as top secret the nature of the disease between himself and the doctor. Modern professional medical ethics also require that doctors do not disclose the nature of their patients' diseases. Among the Africans, however, the problem of an individual is shared by the community. The search for healing is therefore the responsibility of all . This is demonstrated among the Gikuyu by the fact that often family members either accompanied the sick person or went on behalf of the sick person to the medicineman. They had to participate in the diagnosis of the problem. The following account by an informant illustrates this participation.

The step-mother of Wambugu had been sick for some weeks. Despite taking herbs her condition was getting worse. Wambugu by then a young man in the 1950's was asked by his father to accompany three other old men to a renown medicineman to find out the cause of his step-mother's problem. Before they got to the home of the medicineman, their leader asked them to collect six different sticks each of which represented a possible cause of the sickness. These were to be given to the medicineman on arrival and were to be used during the diagnosis. At the end of the session the medicineman told them that the cause of the woman's suffering was an unpaid dowry. According to Wambugu his father later paid the remaining dowry and the woman recovered her health

For Africans, the healing process is a holistic event touching on basically all faculties - physical, social, emotional and spiritual, as well as involving other members of the family. The cleansing rituals that followed marked a new start in life symbolized by shaving the hair, lighting a new fire, or sweeping the house ceremoniously. Such rituals may not mean much to an observer, but as Mbiti notes, they are psychologically vital and no doubt play a great role in healing the sick or helping the sufferer (Mbiti 1969, 169).

From the foregoing account of the procedure of healing among the Gikuyu, we note the following four important aspects. First, there was the recognition of the role of the medicineman as one gifted with special powers by God for the service of his people. (Gathigira 1932, 57). Second, the individual was required to confess any evil he/she 
had committed. Third, there was the communal aspect in both the diagnosis and the rituals. Fourth, there was the significance of rituals in the healing process.

Examples of similar healing processes can be cited from other African communities. Magesa $(2004,65)$ has documented recent case studies from Tanzania on traditional healing among the catholic faithful which further demonstrate the persistence of the quest for healing to the present. One of the cases is of a retired catechist who had lost his wife and had remarried. Soon after his new marriage he began to have frequent dreams, in which his deceased wife would appear expressing her discontent with the second wife. After consulting with members of his Small Roman Catholic Community and the parish priest, he decided to perform a sacrifice to his deceased wife according to the Wangoni custom.

During the Wangoni ritual, a woman addressed the spirit of the deceased wife. First she spelt out the purpose for the gathering in the home. This was followed by an explanation as to why the husband had married the second wife, namely, to have someone to take care of the children she (the deceased wife) had left behind. The woman then assured the deceased that everyone in the family still loved and remembered her. After that she pleaded for forgiveness in case anyone in the family had wronged the spirit in any way. Lastly, the spirit of the deceased wife was invited to join the family members, to protect and guide them in all their activities. The last part of the ritual was the feasting and dancing by all those who were present. During the feasting which included the meat of the sacrificial animal, the bones were thrown on the ground and any food which fell on the ground was left for the spirits. After this reconciliatory ritual the problems of the retired catechist came to an end.

The above account illustrates a broken relationship which required healing. The sufferer could not get a solution from his church, and this forced him to revert to the traditional healing practice. Although the problem was between the husband and his deceased wife, eventually it affected the whole family. This is why all the family members had to be present during the reconciliation ritual. Relatives and neighbours were also invited to witness the ritual. Unlike the case of Wambugu discussed earlier, here we have a situation where a committed Roman catholic faithful reverts to the 
traditional form of healing and finds no contradiction in his faith. It is these practices that the Western missionaries condemned as paganism, and sought to replace with modern medical practices as illustrated in the following section.

\section{The Impact of Western Christian Missionaries on Gikuyu Healing Practices}

The arrival of Western missionaries in different parts of Africa in the $19^{\text {th }}$ century brought with it teachings that not only challenged, but also condemned the traditional approaches to healing (Kibicho 2006, 47-53). The medicinemen, who were highly respected for their services, were termed "witchdoctors" by the Europeans (Magesa 1998, 165). The whole African process of healing was in the eyes of the European missionaries part of a wide scheme of witchcraft and paganism, and had to be eradicated in order to pave the way for Western civilization and the Gospel. It is for this reason that most mission stations had the four pillars of Western civilization, namely, the school, the church, a health centre, and a farm to generate some income. The schools and the health centers were however used as points of converting Africans (Anderson 1970:107).

Among the Gikuyu for example, the Church of Scotland Mission came up with a priority list of the traditional practices that had to be done away with. According to Macpherson $(1970,105)$, they were put into the following categories:

(i) Beliefs and customs regarded as being at variance with Christian principles but not necessarily actively opposed to them and therefore to be allowed to die out of their own accord. These included deference to ancestral spirits, the traditional sacrificial system and the practice of magic and "ugo"

(ii) Customs regarded as incompatible with Christian principles and therefore unacceptable in a Christian community such as polygamy and sexually motivated dances.

(iii) Customs regarded as medically or hygienically undesirable to be actively taught against such as the exposure of the dead and female circumcision.

Thus according to the missionaries, the practice of traditional healing ( $U g o$ ) was at variance with Christian teachings. To discourage it, they set up health centres in their missions, to which they referred the sick among the African converts. However, the 
missionaries did not come up with a substitute explanation for the causes of the sickness that was satisfactory to the African converts. A spiritual vacuum was thus created among the African converts. This vacuum has been filled in the African Instituted Churches as we shall see in the next section. The concept of healing in these churches is holistic after the manner of the traditional African approach. It is therefore not accidental that these AICs are drawing followers either as part-time or full-time members from the main line churches, which have not addressed these issues adequately. For example, Rene De Haes (1988) has observed that in the city of Kinshasa the reality is undeniable that Christians are leaving the traditional mission churches to look for salvation elsewhere where their aspirations seem to be better addressed. West $(1975,120)$ has made a similar observation in his study of AICs in South Africa:

One of the important reasons that people leave the mission churches and join independent churches is that they are able to satisfy certain needs that cannot be met in most mission churches. And healing, particularly of "African Complaints" is an important factor.

\section{Faith Healing In the Akurinu Churches}

\section{Background}

The Akurinu Churches emerged among the Gikuyu community during the socially and politically troubled period in Gikuyuland in the late 1920's (Kinyanjui 1973; Murray 1973). Like other AICs among these people, such as the African Independent Pentecostal Church of Africa (AIPCA), the Akurinu were reacting to the social, political, economic and cultural pressures brought upon the Gikuyu by the British colonial administration and Western Christian missionaries. Their reaction took a religious orientation, as they prayed for the liberation of the country. The Akurinu however claim that their church was founded through the Holy Spirit, for just as God had chosen the House of Israel, he wanted to establish a people among the Africans through whom he would reveal his will. It was for this reason that the early Akurinu called themselves “Watu wa Mungu” meaning, "the chosen people of God(Kenyatta 1938, 275). The accounts of the early life of the Akurinu mention the giving of the Law on Mount Kenya to guide this new community. The practices in the Akurinu churches have been influenced by these laws to the present. The practice of faith healing is similarly based on this belief as we shall see in the next section. 


\section{The Basis of Faith Healing In the Akurinu Churches}

The Akurinu Churches have practiced faith healing since their inception. Four factors can be identified as forming the basis of faith healing in these churches:

\section{(i) The Mount Kenya Law}

Among the members of the AIC under study, it is claimed that in 1930, eight Akurinu elders were told through a revelation to go to Mount Kenya to receive the guiding law(Ndungu 1994, 111). Reportedly, the elders' experiences on the mountain convinced them that God had appeared to them: there was thunder and lightning, a rainbow and a trembling of the earth, similar to the experience Moses had on Mount Sinai when he went to receive the Decalogue (Ex.19: 16-19). Among the 11 commandments that the Akurinu elders were allegedly given, two are important for our present study. The secon ${ }^{\mathrm{d}}$ Mount Kenya commandment prohibits its adherents from going for treatment in Western-type hospitals due to the Europeans' hypocrisy, since the colonialists were opposed to the new movement of the Akurinu. The thi ${ }^{\text {rd }}$ Mount Kenya Commandment requires the Akurinu to refrain from using the things brought by Europeans, and to reject their teachings.

The founders of the Akurinu churches therefore rejected western formal education and medicine. Indeed, they made it an ecclesiastical requirement that none of their followers would go to hospitals and that their children would not go to school. The main reason advanced for the rules was the fear that the Europeans would use their medicine to eliminate the Gikuyu leaders in the same way the Pharaoh had planned to eliminate the Jewish baby boys in Egypt (Ex.1:15-22).

\section{(ii) Belief In The Holy Spirit}

The Akurinu fall under the category of Spirit churches (Murray 1973) - they claim to be guided by the Holy Spirit whom, they assert, is continually present among them. They therefore attribute most of their practices to the Holy Spirit, who they say directs them through prophecy, visions and dreams. They further assert that when God commanded them to abandon Western medicine, the Holy Spirit directed them to 
resort to prayers whenever they fell sick, and they would be healed. Furthermore, while some members were allegedly given the power to prophesy, others were reportedly given the power to pray for others. Kenyatta(1938, 276) confirmed this when he observed:

Watu wa Mungu (Akurinu) being the chosen people, naturally believe that they possess these powers and they go about trying to heal the sick. Sometimes they succeed in doing so and this gives them more prestige among the indigenous population.

\section{(iii) The role of the Bible}

The early Akurinu leaders spent four years (1927-1930) searching for guidance from the Bible on how to steer their new church ( Ndungu 1994, 109). Whenever an issue arose such as sickness, those who were literate among the elders turned to the Bible to search for a solution. There they found that prophets such as Elijah and Elisha performed healing miracles (2 Kings 4:18-32; 5:1-14). The Akurinu viewed themselves as God's prophets (Anabii), and therefore believed they had similar powers to effect healing through prayers. Moreover, both Jesus and the Apostles performed healing miracles (Mathew 11:4-5; Mark 6:13; Acts 3:1-16, 8:7, 9:32-42).

\section{(iv) Influence of former traditional healers}

Before they converted to Christianity, the Akurinu were leading the Kikuyu way of life, in which the medicineman (Mundu Mugo) played an important role in the lives of the people. Some members like Jason Warii is reported to have been a medicineman before he became a Mukurinu (Ndungu 1994, 385). Thus the practice of healing was not new to them. The difference was in the new procedure the Akurinu adopted based on their reading of the Bible.

\section{Healing In The Akurinu Constitution}

The stand of the Akurinu churches as regards matters of personal health is spelt out in their constitutions, copies of which are given to the Government (Registrar of Societies) during their registration. As the articles of their constitutions below illustrate, the Akurinu Churchs have clearly expressed their stand with regard to the use of Western medicine and the role of faith healing among their members. 
(i) Holy Ghost Church of East Africa Rule No 8 states:

We do not take medicine or receive medical care. When any of us falls sick we pray for him/her (James 5:3-6)

(ii) Christian Holy Ghost Church of East Africa Rule 17 states:

We do not use modern medicine (or injection or any medicine) neither do we consult medicine men. We pray Jesus Christ and he helps us. Jer. 46:11-12, Rev. 18:23-24; Hos. 5:13-14; if any one of us is ill we pray for him.

(iii) African Christian Holy Ghost Church Rule 13 states:

We do not take any kind of medicine or inoculation, and we are not connected with African witch-craft doctors; see Deutronomy 18:9-16; Jer.46:11-12; Numbers 6:1-5; Rev.18:23-24; Hose 5:13-14. If our members are sick or get illness we go in his house and pray our Almighty God, we believe in that. See Jacob (James) 5:14, John 11:25, Acts 19:12-13 (cited in Ndungu 1994, 216).

These official statements apply to other Akurinu churches as well. As earlier noted, the Bible is used as the basis for their faith healing. They disassociate themselves from the traditional medicinemen as well as from witchcraft. The following section looks specifically at the procedure for healing in these churches.

\section{The Healing Procedure in the Akurinu Churches}

Until recently, the Akurinu churches were ridiculed by the community. This was partly due to the ignorance of most people concerning the activities of these churches. It was also due to the fact that the Akurinu themselves remained an exclusive community, generating suspicion and false accusations. Like other AICs (Oduro 2003), the Akurinu churches are viewed as institutional outfits of the unsophisticated and poor members of society. Their healing activities have therefore been mainly among their own members and those non-members who due to their unresolved problems have decided to join the Akurinu churches hoping to get solutions to their problems. However, the opening up of the Akurinu churches especially in the urban areas is changing these old attitudes. It is common today to see non-members attending and participating in the Akurinu open services. When in such gatherings people with problems are asked to come forward for prayers, the non-members also join them. 
It is also noteworthy that the Akurinu do not advertise their healing activities as do the charismatic movements. In addition, while in the charismatic movements those who seek healing have usually exhausted all other avenues, the Akurinu as noted earlier are not supposed to seek other forms of healing. The law which was allegedly given to their elders at Mount Kenya forbade them to use Western medicine, and so they rely on prayer alone. Conservative members of the Akurinu churches continue to hold on to this teaching.

In the understanding of the Akurinu churches, there are two categories of healing. First, there is the healing that is conducted as part of the service. This usually comes at the end of the service, when the preacher calls for all those with diverse problems (be they physical, mental or social) to come to the front next to the Kigongona (sanctuary). The following incident illustrates this category of healing:

The people who had come to the front were asked by the bishop each to pray for himself or herself first. Then he asked each person to touch the paining part or organ of the body and each person put the hand on a part of the body, some pointing to more than one part as an indication of multiple suffering. While in this position the Bishop prayed for them with his hands raised and stretched over their heads. The elders in the sanctuary also prayed individually but loudly with their hands raised. The junior elders were surrounding the sick people with their hands raised as the bishop prayed. The prayer was concluded in the following manner.

Bishop - Say - forbearance be shown to them.

Congregation - Forbearance be shown to them.

Bishop - Say - They be forgiven

Congregation - May they be forgiven (Ndungu 1994, 216).

From the above incident, we make the following observations:

* The ceremony is formal (prayer).

* No diagnosis is involved.

* The suffering is attributed to misdeeds, broken relationships or sin.

* God's intervention through forgiveness can restore their health.

* For the success of the healing the individual person takes the initiative and is involved in the prayer. This is similar to the confession of all evils done in the traditional healing procedure. 
* There is communal participation, which ensures that the sick are comforted by being made to feel that their suffering is shared by the rest.

The second category of healing involves the patient and the prophet healer. This is more of a private consultation. As in the traditional Gikuyu consultations with a medicineman discussed earlier, the patient may be accompanied by relatives to the prophet-healers, who deal with all forms of afflictions such as sickness, domestic quarrels, barrenness and unemployment. Their role is to identify the cause of the problem and to provide remedies, and to give an assurance that the problem will not recur. In this respect they compare favorably to the traditional African healers and hence their popularity not only among the Akurinu, but even among the non-members who also consult them. The following account of prophetess Ruth Muthoni sheds more light on this form of healing.

Muthoni uses prayers for her faith healing but at times she places the Bible on the patient as she prays. She has to be in her worship robes with her shoes removed. The prayer hours are at 9.00 a.m., 3.00 p.m. and 9.00 p.m. from Monday to Saturday, unless there is an emergency. On Sunday she has to be at the service. Observing Muthoni at work in her rented one-room house cum clinic is both interesting and fear instilling. The following healing sessions are more revealing:

It was the 9.00 a.m. healing session and being a Monday, several people were streaming in some having spent the night in Muthoni's house. She checked at her watch and announced that it was time and all the ten people present were told to get inside and remove their shoes. At $9.00 \mathrm{a} . \mathrm{m}$. she began to pray and would often break into speaking in tongues. Then she began to reveal to each person the cause of the sickness or other forms of suffering. This she did openly as all those present listened. For some, they were told that their messages had not been received and should wait for the afternoon session. It is after identifying the cause of the problem that Muthoni prays for the sick person individually (Ndungu 1994, 391).

Apart from dealing with physical ailments, Muthoni, like other prophet-healers, also deals with other personal afflictions which modern medical practitioners may not handle. The following incident illustrates this form of healing:

Esther Njeri is a retired civil servant. In August 2004, she had a chain of problems which were distressing her. First her goats and sheep started disappearing and the herdsman complained that he could not 
understand how they were getting lost. Second, a fire broke out and consumed all the grass pasture on her piece of land putting her animals at risk. The cause of the fire or who started it was unknown. Third, she complained of mysterious insects invading her bed at night yet she could not see them. Fourth, during this month, her vehicle started breaking down whenever she wanted to go out.

Njeri decided to seek help from her church, the Presbyterian Church of East Africa (P.C.E.A.), one of the mainline Churches. She requested the church elders to hold prayers in her house in a bid to get rid of her problems. Despite the prayers, however, her problems persisted. It was out of this desperation that Njeri decided to approach Prophetess Muthoni to find out the cause of her problems.

The prophetess then prayed, after which she informed Njeri that her predicaments were due to her hard- heartedness towards the Holy Spirit. She had persistently refused the gift of the Holy Spirit and therefore what she was going through was the beginning of a series of sufferings aimed at softening her heart. With this explanation Njeri left her old church and immediately joined the Akurinu church. She put on the white veil and the long flowing white dress worn by the Akurinu women. Apart from that she began to carry a rod which she claimed she was commanded to carry through a vision. To her gratification her problems came to an end (Interview,28/8/2004).

The above account reveals that the prophet healers' approach to solving their clients' problems is similar to the healing rituals in the traditional African communities. The Bible, for instance, is used as a substitute for the traditional paraphernalia of the traditional medicine people - it becomes a magical tool used to drive away evil spirits and in the diagnosis of the sickness (Mwaura 2002, 305). The prophet-healer creates an atmosphere of awe, although reference is made to God rather than to the spirits. The explanations given for the causes of the problems are not only reassuring, but also provide guidelines on the way to the restoration of the broken relationships. It is this approach to holistic healing which is lacking in the mainline churches, thereby driving people to the AICs where it is readily available. Kyomo ( 2003) makes a similar observation:

My research on healing in African context has enabled me to realize the reason behind the rapid spread of African Independent Churches in our continent. It is because healing in these churches is at the centre of their worship. Christians find themselves to be quite at home as the practice of healing is rooted deeply in their minds, having some roots from the African traditional religion. It should be noted however that some churches have taken faith healing as the only option for dealing 
with all forms of sickness and despise modern medicine (Kyomo 2003).

We noted above that Isaih Shembe had prohibited his followers from using the western medicine (Sundkler 1964, 227). Similarly,some of the Akurinu churches rejected western medicine, and relied on prayer alone for their healing. It was in 1969 ,after Government intervention, that some of them agreed to go to hospital (Ndungu 1994, 386). Such an extreme stance is contrary to the traditional African spirit of healing: the Africans used all available options, including prayers and herbs in order to save and promote life.

\section{CONCLUSION}

This article has examined the practice of healing in the African Instituted Churches, with special reference to the Akurinu churches of central Kenya. It has shown that the quest for holistic healing continues to preoccupy a sizeable number of African Christians, not just those from the AICs. The mushrooming of charismatic churches in Nairobi such as the Maximum Miracle Centre, Winners Chapel and Jesus Is Alive Ministries all of which claim to provide such services, attests to this demand.

Healing as practiced in the AICs addresses issues of great concern to the African personality - the cause of the occurrence of problems. The methods used which involve diagnosis, explanation and prescription of solutions to the problem gives the victim an assurance that all will be well. Through the diagnosis the unknown is made known, and the fear that was there is replaced by understanding. With this understanding and acceptance, satisfaction is attained even if a complete cure or solution may not have been achieved.

The overriding lesson of the foregoing discussion is that the churches in Africa need to be authentic enough to deal with their adherents' problems in a practical way. So far the Churches have not come to grips with the emotional, moral and spiritual needs of the people (Mwaura 2002, 121). The fear by Christians of sorcery, witchcraft and curses is undeniable, so that brushing it aside as paganism is not a solution. We need to find meaningful ways of dealing with it, and the Akurinu churches have 
endeavoured to meet this need for their adherents. Healey and Sebertz have made an appeal for the inculturation of healing thus:

One of the great challenges of the inculturation of the gospel in Africa today is to overcome and breakdown the dualism and parallelism between Christianity and African traditional religion. This means living one holistic world rather than trying to balance two worlds. [ Healing] was an important priority in the Old testament and Jewish tradition and an important part of Jesus Christ's teaching and ministry. Healing was also very important in the early Christian church, yet ironically the healing aspect of ministry has been inculturated in only some Christian churches in Africa today, such as the African Independent Churches and different types of Pentecostal churches (cited in Kyomo 2003).

The African Christian continues to have a fragmented worldview, which requires a healing process to facilitate meaningful inner integration. Inculturation should therefore move from the periphery to the core of the African life (Walligo et. Al. 1986; Chepkwony 2005). Introduction of drums and African tunes in the churches is not enough: there is need to address those practices that touch on the roots of African spirituality and world view. In Chipenda's words, "we should make an effort to make the gospel penetrate the inner circle of every and each culture" ( Chipenda 1987). The experiences of the AICs, and in particular those of the Akurinu churches regarding holistic healing, could be of help towards achieving this goal.

\section{References}

Anderson, J. 1970. The Struggle for The School. Nairobi: Longman Publishers.

Bond, G. et. al. eds. 1979. African Christianity: Patterns of Religious Continuity. New York: Academic Press.

Chepkwony, A.K. 2005. "African religion: The Root Paradigm for Inculturation Theology: Prospects for The $21^{\text {st }}$ Century". Ndung'u N.W and P.N. Mwaura eds. 2005. Challenges and Prospects of The Church in Africa: Theological Reflections of The $21^{\text {st }}$ Century. Nairobi: Pauline's.

Chipenda, J.B. 1997. "Culture and The Gospel in Changing Africa". Mugambi, J.N.K. ed. 1997. The Church and The Future In Africa: Problems and Promises. Nairobi: AACC.

Gathigira, S.K. 1932. Miikarire ya Agikuyu. Nairobi: Equatorial Publishers.

Gifford, P. ed. New Dimensions in African Christianity. Nairobi: AACC. 1992.

Haes, Rene De. 1998. "The Proliferation and Persistence of New Religious Groups in the City of Kinshasa: Some Case Studies". in Gilford, P. ed. New Dimensions in African Christianity. Nairobi: AACC.

Kenyatta, J. 1938. Facing Mount Kenya. London: Secker and Warburg.

Kibicho, S.G. 2006. God and Revelation in an African Context. Nairobi: Acton Publishers. 
Kinyanjui, E. 1973. "The Rise and Persecution of The Aroti Prophets 1927-1948". Barret, D.B. et. Al. eds. Kenya Churches Handbook. Kisumu: Evangel Publishing House.

Kyomo, A.A. 2003. "Faith and Healing in the African Context". Vahakangas, M. and A.A. Kyomo eds. 2003. Charismatic Renewal in Africa: A challenge for African Christianity. Nairobi: Acton.

Leakey, L.S.B. 1977. The Southern Kikuyu Before 1903. London: Academic Press.

Magesa, L. 1998. African Religion: The Moral Traditions of Abundant Life. Nairobi: Paulines.

--. 2004. Anatomy of Inculturation: Transforming The Church in Africa. Nairobi: Pauline's.

Martin, M.1. Kibangu. 1975. An African Prophet and His Church. Moore, D.M. Trans. Oxford: Blackwell.

Mbiti, J.S. 1969. African Religions and Philosophy. Nairobi: Heinemann.

McPherson, R. 1970. The Presbyterian Church in Kenya: An Account of The Origins and growth of the Presbyterian Church of East Africa. Nairobi: Presbyterian Church of East Africa.

Murray, J. 1973. "Varieties of Kikuyu Independent Churches". Barret, D.B. et.al. eds. Kenya Churches Handbook. Kisumu: Evangel Publishing House.

Mwaura, P. 2002. "A Theological and Cultural Analysis of the healing in Jerusalem Church of Christ and Nabii Christian Church Of Kenya". Ph.D Thesis, Kenyatta University.

Ndungu, N.W. 1994. "The Akurinu Churches: with special Reference to their Theology". Ph.D Thesis, University of Nairobi.

Oduro, T. 2004. "Theological Education and Training: Challenges of African Independent Churches in Ghana". Journal of African Instituted Church Theology, vol.2 No.1, p.42.

Pontifical Council for Culture. 1999. Towards a Pastoral Approach to Culture. Nairobi: Pauline's.

Rukwaro, R.W. 2005. "Inculturation of the Catholic Church in Kikuyu Religious Space". Hekima: Journal of the Humanities and Social Sciences, Vol.3 No.1, 2005, pp.102-117.

Shorter, A. and J.N. Njiru. 2001. New Religious Movements in Africa. Nairobi: Pauline's.

Sunkdler, B.G.M. 1964. Bantu Prophets in South Africa. London: Oxford University Press.

Turner, H.W. 1967. History of an African Independent Church: The Church of the Lord (Aladura), Vol.I. London: Oxford University Press.

Vahakangas, M. and A.A. Kyomo. Eds. 2003. Charismatic Renewal in Africa: A challenge for African Christianity. Nairobi: Acton.

Walligo, J.M. et. Al. 1986. Inculturation: Its Meaning and Urgency. Nairobi: St. Paul's Publications Africa.

Ward, E. 2002. "Similarities and Differences in Cross-Cultural Pastoral Supervision". Journal of Theology for South Africa, July 2002, pp.51-64.

West, M.E. 1975. Bishops and Prophets In a Black City. Cape Town: David Philip. 